doi: 10.52370/TISC21127CM

\title{
IMPACT OF THE COVID-19 PANDEMIC ON THE TOURIST OFFER AND AGRICULTURAL DEVELOPMENT IN THE MUNICIPALITY OF KUČEVO
}

\author{
Cvijan Mekićl ${ }^{1}$ Milivoje Ćosić ${ }^{2}$
}

\begin{abstract}
The corona virus pandemic has imperilled tourist destinations around the world, completely disrupting all types of traffic and border traffic. The global corona virus pandemic has brought with it major changes in trade, industry, agriculture and transportation. The negative effect of the pandemic on agriculture is reflected in the loss of the market. Tourism and catering are affected first, as arrangements are canceled and people go out to restaurants less. The next important branch that got affected is industry due to supply chain disruption. Economic activity has pretty much stalled in many sectors, and yet agriculture and food production are mentioned as saviors of national economies. The maxim is known as "there is no stable state without a consistent agrarian policy and a developed agricultural sector". Tourism is an important activity that is seriously counted on in the municipality of Kučevo. The festival of original folk art "Homoljski motivi" is organized in the municipality, moreover, at the territory of the municipality we can find the gold-bearing river Pek and the attractive caves Ceremošnja and Ravništarka. They are tourist content by which the municipality of Kučevo has long been recognizable. The absence of tourist activity on the territory of the municipality of Kučevo affected the reduction of the tourist offer, such as the preparation of traditional food using local products, which all has a negative impact on agricultural production, primarily livestock products.
\end{abstract}

Key Words: Municipality Kučevo, tourism, Covid-19 Pandemic, agricultural development

JEL classification: $Q 1$

\footnotetext{
${ }^{1}$ Cvijan Mekić, PhD, professor, University of Belgrade, Faculty of Agriculture Belgrade, Serbia, 0603337899, cvijanm@agrif.bg.ac.rs

${ }^{2}$ Milivoje Ćosić, PhD, Interkomerc DOO, Terazije 27, Belgrade, micko-cosic@ gmail.com
} 


\section{Introduction}

Outbreaks and global pandemics are the greatest threat to the sustainability of human resilience. Mankind has witnessed many pandemics throughout human history that have killed millions of people and devastated the global economy and politics. Unlike previous food-borne zoonotic diseases, Covid-19 has raised global food safety concerns (World Food Program WFP, 2020a; FAO, 2020a; Torero, 2020a).

Since the outbreak of the pandemic, food purchases made in panic have emerged in many countries, and which is even worse, some countries have considered restrictions on food exports (International Institute for Food Policy Research IFPR, 2020). An extraordinary meeting of G-20 agriculture ministers in April 2020 confirmed the need for collective action to ensure that the market functions well. After March 2020, Covid-19 expanded around the world very quickly. Under the influence of the great lockdown against Covid-19 there was a sudden recession (Torero, 2020b), food systems were at risk as never before, pushing more and more people into poverty, hunger and malnutrition (WFP, 2020b). In addition to the above, the demand for food of animal origin has decreased. During the H1N1 pandemic in 2009, 64\% of consumers in China stopped buying pork, bringing \$ 270 million in losses to the American Pig Association in the second quarter of 2009. (Gong et.al.,2020). The Covid-19 epidemic is hitting densely populated areas and larger cities harder than rural areas (Reardon et al., 2020). Covid-19 destroys the agricultural production sector. Even in developed countries like the United States and Canada, excessive stocks of milk, vegetables, livestock and poultry have emerged. (Weersink et.al., 2020, Bellany \& Corkery, 2020).

Macroeconomic trends in the global world economy indicate a decline in overall economic activity, which can be compared to the Great Depression of the last century, which lasted from 1929 to 1933. All the existing and realistically observable elements of the current economic situation show that the appearance of the corona virus is going to leave huge consequences on the economy and the world economy as a whole.

The consequence of the corona virus will lead to a drastic decline in the world economy, because all economic branches, including the tertiary sector, will have great losses in 2020, and possibly in the following years as well. Production has been completely stopped in certain areas of the economy, and some sectors produce only what is necessary to preserve the 
functioning of the economic system. Also, activities in tourism, transport and other services have been completely suspended, which will cumulatively lead to a drop in the rate of economic growth and development. In the first five months of 2020, the total number of tourist arrivals in Serbia decreased by $52.8 \%$ compared to the same period in 2019. In May 2020, the number of tourist arrivals decreased by $87.6 \%$ compared to May 2019, and when it comes to foreign tourists, this decrease is $97.8 \%$.

The perception of risk in health crises is often higher in relation to the real danger of infection. Studies show that their impact is smaller on those tourists who have visited a country affected by the health crisis in the past.

In any case, in addition to providing conditions for combating the spread of the disease, it is important to provide as much information as possible. Representatives of the tourism industry often do not provide enough information in their brochures or websites thinking that this will spread fear, while consumers should be aware of the risks and precautions they should take. A good example was shown by the Pacific Asia Tourism Association (PATA) during the crisis caused by SARS, undertaking a number of public information activities in order to restore trust in the region. When it came to the appearance of bird flu, PATA already had a concept prepared. They provided timely information on the dangers of this flu and ways of transmission. The notifications were harmonized with the WHO.

Tourism is an economic activity that is seriously counted on in the municipality of Kučevo. Due to the Covid-19 pandemic, there was no tourist activity in 2020, because there was no tourist activity within the tourist offer. On the territory of the municipality of Kučevo, there are numerous tourist destinations and festivals of original folk art.

The aim of this paper is to point out the perspectives of tourism development and agricultural production in order to increase the tourist offer using tourist potentials and local products.

\section{Impact of Covid-19 on tourism in the Republic of Serbia}

There are slightly more than 83,000 people in Serbia who are engaged in hotel management, according to the data of the Republic Bureau of Statistics. A good year for Serbian tourism was 2019, because for the first time the number of foreign tourists exceeded the number of domestic ones, 
with more than 10 million overnight stays, according to the data of the Ministry of Trade, Tourism and Telecommunications. The pandemic especially endangered tourist guides and companions. There are no more group trips, especially when it comes to foreigners. In addition to the crucial changes we have encountered, such is a change in the way we work, we have lost the opportunity to provide ourselves with those pleasures that are the bright spots of our days. We began to realize the value of small things, which we considered natural, only when we realized that they could become very inaccessible. Travel is undoubtedly one of such situations, that makes everyday life more beautiful, and which at one point became almost impossible.

Tourism is an area that may have suffered the greatest consequences during the pandemic. At the same time, we realized how much we need this area and how much its unlimited availability affects our quality of life.

Observed statistics show that we did everything to escape from the cities and find peace in the greenery of conifers, calmness of blue waters and mountain slopes.

\section{Potentials of the Municipality of Kučevo from the aspect of tourism development}

The municipality of Kučevo is located in the southeastern part of the Braničevo district and covers the extreme slopes of the Homolje Mountains with a gradual transition to the Stiška valley. It covers an area of $721 \mathrm{~km} 2$. The average altitude of the whole area is $280 \mathrm{~m}$, and the highest peak is Stubej, whose height is $940 \mathrm{~m}$. The municipality is well connected with all parts of the republic.

\section{Kučevo - old mining area}

Zvizd is an old mining area where the Celts, Romans, Slavs and Serbian kings searched for gold. The area of Zvižd was, thanks to its natural resources, interesting to people even in prehistoric times. Thanks to its mineral wealth, this area was significantly inhabited in both the ancient and medieval periods. On the territory of the municipality of Kučevo, the Romans intensively exploited iron ore, gold and silver from the nearby mines. Numerous cultural and historical monuments and remnants of material culture from this period testify to these events. 
The most important cultural monument is "Kraku lu Jordan". "Kraku lu Jordan" is the most important archeological and metallurgical ancient site from the period of the 3rd - 5th century AD in this part of Serbia. It was surrounded by strong fortifications inside when a foundry of iron, lead, gold and silver and other metals functioned. Castings (ingots) of these metals were found. The site is located at the mouth of the river Brodica in Pek, in the village of the same name Brodica. It represents a cultural asset of exceptional importance in the Republic of Serbia. Since the gold coin with the image of Emperor Hadrian was found in Kučajna, it can be claimed with certainty that the Romans were on the territory of the municipality of Kučevo in 128 AD. Gold, silver and iron from the mine were stored in a fortification located near the confluence of the Kučajska River and the Pek River. The name of that fortified city was Guduskum.

The municipality is rich in ores, agricultural and forest land. The municipality of Kučevo is located in the temperate-continental climate zone, and in the higher parts there is a transition to the mountain type. The main features of this climate are long and cold winters and warm summers. The average annual precipitation is about $750 \mathrm{~mm}$. The average annual air temperature is around 11C. The relief of the wider surroundings of Kučevo is complex and diverse with meso and microforms of denudation, fluvial and karst relief. There are two geographical units: plain and hillymountainous part, upper and lower Zvižd. This relief, as well as the pedological and hydrographic characteristics of the land, determine the manner of its use.

In the structure, agricultural land occupies 34,532 ha or one half of the total area of the municipality, while, in the other half, 34,820 ha is under forests and the remaining part occupies 2,748 ha of land. Of that, 16,119 ha are arable land, and the remaining part of the agricultural land is pastures and meadows. The river Pek flows through the municipality of Kučevo, which is a right tributary of the Danube and, on the territory of the municipality, it represents the largest river flow that flows along the entire length of the territory. The height difference from the mouth to the source of Pek is 725 $\mathrm{m}$ with an average drop of $6.25 \%$. The stream itself is $120.20 \mathrm{~km}$ long, and the catchment area is $1326 \mathrm{~km} 2$. The average flow of the river is about 7.5 $\mathrm{m} 3 / \mathrm{s}$. Significant tributaries for the entire water regime are the Komša and Kučajska rivers on the left and the Ševica and Posuška rivers on the right. The municipality is very rich in mineral raw materials and had a very long tradition of lime and stone production, while the exploitation of quartz is of more recent date. The entire area of the municipality is very rich in ore 
and coal, and exploratory exploitation of gold with pit excavation is in progress.

\section{Agriculture}

Observed through the time from the end of the last century to the present day, there is a noticeable decline in the number of inhabitants in the municipality of Kučevo and beyond, i.e. in the Braničevo district and in the Podunavlje district, as well as a decline in agricultural and rural population engaged in agricultural production. According to the data of the last census of agriculture in the Republic of Serbia in 2012 in the municipality of Kučevo, the number of agricultural farms is 3,694, with agricultural households using a total of 11,622 hectares of agricultural land.

The main characteristics of agricultural farms on the territory of the municipality are very fragmented farms and a very small total area of cultivated agricultural land per farm: 977 households with a total of 610 ha of agricultural land have up to 1 ha of agricultural land at their disposal, 807 households using 1,165 ha of agricultural land have 1-2 ha of agricultural land, 1245 households using 4,029 ha of agricultural land have 2-5 ha of agricultural land. 5-10ha and more of agricultural land is available to 503 households that use 416ha of agricultural land. There are 26 households that do not have agricultural land. The total area of agricultural land, based on cadastral data, is 34,800 ha, and if we compare these data with the data from the 2012 agricultural census, we will notice that $2 / 3$ of the agricultural land in the municipality is unused.

According to the data from the Statistical Office of the Republic of Serbia, according to the last census of agriculture, the municipality has: 1,634 head of cattle, and accommodation capacity for 9,933 head of cattle in 2,186 buildings, 11,211 pigs, and accommodation capacity per farm for 38,682 in 3,195 buildings, 10,984 sheep, 1,695 goats, 64,584 poultry and 5.389 hives.

Based on the presented data, we can unequivocally conclude that the livestock is very impoverished, regardless of the potentials and the existence of already built facilities for livestock breeding. From all the above, there is a clear need to build facilities for the processing industry, primarily at least one other slaughterhouse and at least one dairy, which would provide agricultural producers with a permanent and safe placement of agricultural products and thus directly encourage the production of large 
animals - cattle, pigs, sheep and goats. As for other branches of agricultural production, there is a noticeable trend of growth in the number of hives and agricultural producers engaged in beekeeping.

A special problem that Covid-19 brought was the impact on the labor force in agriculture, especially in labor-intensive productions such as fruit and vegetable growing. Necessary seasonal workers are irreplaceable during the agricultural season and they often work illegally, without health care, and if they get sick, they will be unable to return to their jobs for weeks. The market chain in agriculture is complex, if in some part there is a problem, production stops or slows down on the way to the consumer. Of course, it is difficult to predict the effects of Covid-19 when the virus is still spreading around the planet, but it is clear that its economic consequences will be devastating and long-term. Agriculture recovery measures are primarily fiscal and monetary.

\section{Tourism}

Tourism is an economic activity that is seriously counted on in the municipality of Kučevo. The festival of original folk art, "Homoljski motivi", the gold-bearing river Pek and the attractive caves Ceremošnja and Ravništarka, are tourist contents that the municipality of Kučevo has long been recognizable by. However, the region has a much greater tourist potential, which could be activated relatively quickly with adequate investments and strengthen the existing active tourist offer. The most important segments of the tourist offer of the municipality of Kučevo are reflected in the following contents:

Caves: Ravništarka Cave is one of the most beautiful and well-kept caves in Serbia. It is located near the village of Ravnište, $12 \mathrm{~km}$ south of Kučevo, in the hills of the Homolje Mountains, on the road to the Ceremošnja Cave. The length of the hiking trail in the cave is $550 \mathrm{~m}$. A protection regime of the 2nd degree has been established in the area of the Natural Monument Pećina Ravništarka, which covers an area of 6 ha.

Ceremošnja Cave is $15 \mathrm{~km}$ away from Kučevo. It is located near the village of Ceremošnja, on the slopes of the highest peak of the Homolje Mountains, Veliki Stubej $(940 \mathrm{~m})$. The length of the tourist trail is $431 \mathrm{~m}$. Ceremošnja Cave is widely known for its ornamental wealth and attractive cave halls. Like Ravništarka Cave, Ceremošnja Cave is a protected natural asset - a natural monument of III category (cave and surrounding area of $33 \mathrm{ha}$ ). The 
management of the Natural Monument Ceremošnja Cave is also entrusted to the Tourist Organization of the Municipality of Kučevo. Dubočka Cave is located at the foot of the Zviške Mountains, near the village of Duboka, $12 \mathrm{~km}$ north of the main road Kučevo - Majdanpek. It is $20 \mathrm{~km}$ away from Kučevo. Dubočka Cave is one of the longest caves in Serbia $(2,275 \mathrm{~m})$. This cave, however, is not open for tourists, and it is interesting in terms of speleological-adventure tourism. Particularly attractive is the giant entrance, $25 \mathrm{~m}$ wide and $20 \mathrm{~m}$ high. By making an access road of about 400 $\mathrm{m}$ and a walking path to the entrance to the cave of about $100 \mathrm{~m}$, Dubočka Cave could be an important item in the tourist offer of the municipality of Kučevo.

Ševička Cave is located in the area of the village of Ševica, in the wider vicinity of Dubočka Cave. It is about $17 \mathrm{~km}$ away from Kučevo. So far, 450 meters of the interior have been explored, of which light reaches to the first $70-80 \mathrm{~m}$ and that distance can be crossed without speleological equipment. The cave is quite far from the main road in the village of Ševica and there is an ordinary field road in that section. However, considering that the Ševička Cave is on the route of the mountain trail Rakova Bara Malo vrelo - Rakobarski vis - Dubočka pećina, by arranging this mountain trail, the cave would become more accessible, and the hiking trail could become very attractive. By activating this tourist segment, the Dubočka Cave, as the end point of the mentioned hiking trail, would become more visited.

Historical monuments: Kraku lu Jordan is an ancient archaeometallurgical complex from the 3rd century AD. In the center of the military fortification, there was a large foundry of gold and other metals. The remains of this complex are relatively well preserved. Since 1983, Kraku lu Jordan has had the status of a "cultural asset of great importance". Of the ancient archeological sites, only Viminacium has this status in the Braničevo district. Kraku lu Jordan is located at the confluence of the Brodicka River and Pek, in the vicinity of the village of Brodica, near the main road M-24, Kučevo-Majdanpek, $15 \mathrm{~km}$ east of Kučevo. The summer house of King Alexander I Karađorđević is located in the village of Neresnica, $6 \mathrm{~km}$ east of Kučevo, on the road to Majdanpek. It was built in the 1930s during the reign of King Alexander I Karađorđević. Within the summer house there is a royal villa, a large park and several auxiliary buildings. The history of the summer house is related to the washing of gold from Peka. Namely, the gold-bearing sand was extracted from the Pek by an excavator whose majority owner was King Alexander. The Tourist Organization of the 
Municipality of Kučevo still does not organize tourist visits, but provides all the necessary information so that interested individuals and groups can visit both sites.

Mountain trails: Waterfalls "Malo vrelo" - Rakobarski vis (691 m) Ševička Cave - Dubočka Cave. The length of the trail is about $12 \mathrm{~km}$. Along the trail you can see attractive waterfalls and two interesting caves Ševička and Dubočka. The pedestrian path can be marked and arranged, and in order to become widely used, it is necessary to prepare an access macadam road for bus transportation in the length of about $1 \mathrm{~km}$ - from the village of Rakove Bare to the beginning of the path. Ravništarka Cave Veliki Štubej (highest peak of the Homoljske Mountains with 940 m) Ceremošnja Cave. The length of the trail is $14 \mathrm{~km}$. This is, without a doubt, the best way to experience the beauty of the picturesque Homolje Mountains. The source of mineral water Duboka in the village of Neresnica is located $1.5 \mathrm{~km}$ downstream from the center of the village of Neresnica, at the mouth of the Bukovska River in Pek.

The mineral water spring Duboka rises is at a great depth $(282 \mathrm{~m})$, hence the name Duboka (Deep). It is said that water helps with diseases of the digestive organs, urinary tract and skin. It is drinkable, and it is also excellent as a substitute for ordinary water. Revitalization of this artificial reservoir would provide a pleasant oasis for sport fishermen and other nature lovers. Together with the nearby resort Platan, where at least an auto-camping center could be built, this might become a very attractive natural ambient. Potajnice are a specific hydrological phenomenon, a type of karst springs, in which the intervals of water outflow alternate with drying intervals, and hence "potajnice" or intermittent springs in the professional literature. Appearance intervals of the water, i.e. interruption and rest, last from a few minutes to several hours. This type of springs is a great natural rarity in the world and in our country.

Manifestations "Homoljski motivi": one of the oldest festivals of original folk art in Serbia (1968), that Kučevo has long been recognizable by. It is held in the last week of August, with Saturday being the main day of the festival. During the whole week, appropriate programs are carried out: art exhibitions, concerts, cultural tribines, etc.

The Ethnological Television Film Festival "FESTEF" aims to preserve our ethnological heritage and is held in the second half of October and lasts for 3 days. During the FESTEF, in the accompanying part of the program, 
cultural forums, concerts, exhibitions and other special events are organized, which are interwoven with ethno themes - in accordance with the character of the festival itself. The theater festivities "Žanki u čast" is an event dedicated to Živana Žanka Stokić, a famous Serbian actress. The festivities are held in mid-October and last for 4 days. In those days, our most famous theaters are guests in Rabrovo, and in the accompanying program, exhibitions, cultural tribunes and concerts are held. The village of Rabrovo is located on the main road M - 24: Pozarevac - Kučevo, $22 \mathrm{~km}$ in front of Kučevo, seen from the direction of Požarevac, or Belgrade.

Gold washing demonstration in the Pek River: the Pek is one of the goldbearing rivers in Europe. Gold has been sieved here since the ancient times, with the Ancient Romans being especially successfulat it. With prior notice, the Tourist Organization of the Municipality of Kučevo organizes a traditional gold washing demonstration for tourist groups in the Pek, performed by experienced sievers from Kučevo and the surrounding area.

Rural tourism is insufficiently developed and, in this regard, everything should be done to make rural hosts more interested in this type of tourism, for which the municipality of Kučevo has excellent predispositions.

We should also mention hunting tourism as there are favourable conditions for its development considering that various game is widespread in the area of the municipality. Hunts are organized, mainly for fox, wild boar and wolf. Other game (roe deer, rabbit, badger, etc.) is also present, and from feathered game pheasant and partridge.

In the municipality of Kucevo, folk fairs have retained the charm of the past and represent folk festivals where you can best feel the liveliness and specificity of this area. The main fair is on August 11 (Kalinić). The second, slightly smaller fair is held on September 21 (Mala Gospojina).

\section{Development and improvement of agricultural production in the function of tourism development}

The main characteristic of the decades-long state of agriculture in Serbia is economic devastation and a constant decrease in the income of agricultural producers. This is manifested in varying intensity and modalities through the extraction of surplus value from agriculture, mainly in favor of three sectors: industry, trade and banking. (Mekić \& Novaković, 2013). 
The basis for the development of agriculture and the food industry in Serbia should have a certain oriented concept. Only long-term planned and wellorganized livestock production can contribute to faster development of livestock and thus enable the Republic of Serbia to become competitive on the international market of livestock products (Mekić \& Ćosić, 2019).

According to the 2012 census of agriculture, 2504 head of cattle, 11211 pigs, 10984 sheep and 68842 poultry are reared on the territory and municipality of Kučevo. There is also a decline in production as well as consumption of meat, milk and eggs. The cause of this situation should be sought, among other things, in the disturbed price parities, the loss of the market, the reduced purchasing power of the population, the disturbed financing system, insufficient funds in the agricultural budget, etc. (Mekić $\&$ Ćosić, 2020). Intensification of production in livestock and increasing the share of this activity in the structure of total agricultural production can be provided by changing the racial composition of livestock and increasing production per unit of capacity (Mekić \& Ćosić, 2020). Livestock products have increasing potential for export (Mekić \& Novaković, 2018).

\section{Comparative advantages of the municipality of Kucevo for the development of agriculture and tourism}

The municipality owns:

- Favorable geographical position,

- Natural resources (mineral-raw material complex, thermo-mineral waters, forests, forest fruits, various plant species),

- Ecologically clean territory (Homolje-Kučevo mountains),

- Tradition of production of autochthonous species and products (Homolje honey, cheese, lamb, brandy),

- Attractive tourist destinations and archeological sites, nurturing of Serbian and Vlah culture, recognizable cultural tourist events, existing tourist capacities,

- Existence of facilities (tourist facilities, cooperatives, purchase stations, production facilities),

- Development of rural sports and hunting tourism,

- Joint tourist offer of the region,

- Tender of supply and demand of organic food, medicinal plants and forest fruits,

- Branding of agricultural products, establishment of agro-business centers, 
- Support for the use of alternative energy sources,

- Use of state and other funds.

\section{Tourism and rural development}

Ecotourism as a modern form of selective tourism or tourism with special requirements, is becoming an increasingly important segment of the overall tourism development of many countries at the beginning of the XXI century (Milenković \& Bošković, 2012). The word tourism comes from the English word "Tour", which in the Oxford Dictionary means: the pleasure of traveling, with staying in various places. A tourist is a person who undertakes such a trip (Pejanović \& Vujović, 2008).

Tourist destinations, traditional food, nurturing folk customs and multiculturalism, existence of significant archeological sites, possibility of opening an ethno village with all accompanying facilities, opportunities for the development of rural, hunting, sports and adventure tourism, good geographical position in relation to the main roads, are the comparative advantages of the Municipality development of all forms of tourist offer.

\section{Perspective of development and improvement of tourism and agricultural production}

The specific advantages of the Municipality of Kučevo that are highlighted are: rich nature, healthy environment and good geographical position in relation to the main roads and they are the key forces for economic development. Built local and rural roads, close to the main road M-24 Danube highway, closeness to the national highway, the railway that passes through the municipality in the length of $47.5 \mathrm{~km}$ provides good traffic connections to the municipality. Attractive tourist destinations and archeological sites, authentic and specific customs, old crafts, traditional local cuisine and numerous multicultural events are the basic tourist potentials. The existence of producers with a high breeding culture in the production of indigenous species, suitable terrains for the development of livestock and other branches of agriculture, as households engaged in agricultural production are the forces for the revival of agriculture. The area of the municipality of Kučevo is rich in forest fruits (porcini mushrooms, blackberries, wild strawberries) and autochthonous wild herbs, which is a significant, underutilized advantage. 
In order to complete the tourist offer, to solve the problem of disorganization, a number of holders of the tourist offer have been determined. It is necessary to increase the accommodation capacities and the overall increase of the tourist promotion of the municipality. All these activities would solve the problem of unfavorable age and economic structure, i.e. would reduce the migration of young people and increase their employment in various fields. The chances of the municipality of Kučevo are in connecting the tourist offer of the region, developing attractive types of tourism, monitoring trends in production, greater use of alternative energy sources (thermal water, wind power, solar energy, etc.)

\section{Priority area}

- Improvement of agricultural production and forestry

- Encouraging livestock development and land management plan

For faster development of agricultural production, it is necessary to stimulate the development of animal husbandry as a very important branch of agriculture. This measure would include support for the procurement of breeding animals for the renewal of livestock, as well as for the development of the processing industry, with special emphasis on the construction of a slaughterhouse and dairy in the municipality of Kučevo. This measure also includes the introduction of a land management geoinformation system with an emphasis on agricultural land management and the construction and maintenance of infrastructure facilities in accordance with the land management plan.

\section{Improving beekeeping and bee products}

Encouragement of the development of beekeeping with the use of the convenience of production of honey and bee products in the ecologically clean and unpolluted area of the municipality of Kučevo.

\section{Improving the placement of agricultural products}

This measure implies connecting agricultural producers into associations and cooperatives, which encourages the production and marketing of products. It includes the construction of new facilities, reconstruction and rehabilitation of existing facilities, as well as equipping them in order to purchase all types of agricultural products and forest fruits, in order to preserve the quality of products until the final placement. 


\section{Measures to mitigate the negative effects of the health crisis on tourism}

All crises in tourism require radical management action, in response to events beyond the organization's internal control, which requires an urgent response from marketing and operational practices, in order to restore employee or consumer confidence in the sustainability of the tourist destination or business. To overcome crisis situations, it is important that every business entity and all organizations in tourism act in accordance with applicable legislation in order to create a safe destination. The crisis in tourism must be resolved with significant care, because tourism depends on the consumers and their intentions to stay in a tourist destination or to return to it again. The World Tourism Organization has singled out eight categories of basic measures to mitigate the negative effects of the crisis on tourism, namely: fiscal measures, marketing measures, human resources, public-private partnership, regional cooperation, environmental protection measures and travel facilitation. The biggest problems created by health crises in tourism are related to human health and food safety. Epidemics have negative effects on tourism through a reduction in the number of international arrivals and a significant reduction in the number of air travel, cancellations of sports activities, a huge drop in visits and of income for restaurants, clubs and cafes.

In order to overcome the crisis on the economy and tourism in the Republic of Serbia due to the Covid-19 pandemic, it is necessary to apply financial, tax and other measures for the recovery of the economy and tourism. An adequate response to these challenges requires the coordination and cooperation of all political, economic and social effects and the definition of a set of measures to stabilize the economy.

\section{Arrangement of tourist infrastructure and promotion of tourist potentials}

Intention behind this measure is to renovate the existing and build new tourist infrastructure (access road, hiking trails, parking lots and tourist signs), with an emphasis on tourist promotion and encouraging the local population to make souvenirs.

Environmental protection is of great importance for the municipality of Kučevo, not only from the aspect of protection and improvement of the quality of life and health of people, but also because the unpolluted 
environment is a prerequisite for the development of its economy, agricultural production and rural tourism. In the area of the municipality of Kučevo, a significant number of illegal landfills has been identified, as well as non-compliance with regulations in the waste disposal procedure, so for that purpose it is necessary to educate citizens and expand the number of settlements where waste collection is organized. This measure also includes the rehabilitation and reclamation of the Cerovica landfill in accordance with the adopted project technical documentation, as well as the rehabilitation, reclamation and closure of the existing landfill in Kučevo.

\section{Measures to mitigate the negative effects of the crisis on tourism}

Based on the principles and recommendations adopted by the World Tourism Organization, which have been adopted and implemented by some countries, eight categories of basic measures for mitigating the negative effects of the crisis on tourism can be distinguished: fiscal measures, monetary measures, marketing measures, human resources, public-private partnership, regional cooperation, environmental protection measures and travel facilitation (Unković \& Sekulović, 2010).

The special importance of crisis management in tourist destinations is given by the fact that the tourist, guided by the basic reasons for staying in the destination, is usually in a state of specific relaxation, ability to anticipate possible risks, perceiving dangers and readiness for self-protection. (Popesku, 2011). The crisis in tourism must be managed with significant care, because tourism depends on the costs of consumers and their intentions to stay in a tourist destination, i.e. to return to it again.

Environmental protection will have a great impact on future tourism development. Measures taken in this regard relate to the development of energy-efficient accommodation facilities, reduction of carbon dioxide emissions within tourism, support for transport using renewable energy sources, organization and promotion of events that do not have negative effects on nature, such as cycling festivals or walking marathons, financing the development of green tourism products and conditions, such as hiking, cycling tours, ecotourism and rural tourism.

\section{Conclusion}

Although some crises have a great global impact on the development of tourism, what has always accompanied such phenomena is the fact that 
tourism has always shown an exceptional ability to recover. Every crisis requires an adequate and timely response in order to overcome it. Most often, tourist organizations rely on marketing activities and economic measures, through strengthening propaganda by giving certain subsidies to economic entities in tourism, facilitating travel through visa liberalization, reducing tax duties on investment activities, improving the quality of supply in the tourism sector. The municipality of Kučevo has numerous tourist destinations and events, as well as rich natural resources for the development of agricultural production, which all together gives a comparative advantage for the development of tourism and agriculture in the future.

\section{References}

1. Bellany, D.Y., Corkery, M., (2020). Dumped Milk, Smashed Eggs, Plowed Vegetables: Food Waste of the Pandemic. New York Times. 11 April 2020. https://www.nytimes. com/2020/04/11/business/coronavirusdestroying-food.html (7 July 2020).

2. FAO, (2020a). Impact of the Covid-19 Pandemic on Food Security and Food Systems. FAO Council. CL 164/10, 6-10 July 2020. http://www.fao.org/3/nd059en/ND059EN.pdf (7 July 2020).

3. Gong, B., Zhang, S., Yuan, L., Chen, K.Z., (2020). A balance act: minimizing economic loss while controlling novel coronavirus pneumonia. Journal of Chinese Governance. Vol. 5, No. 2, 1-20.

4. IFPRI, (2020). COVID-19 Food Trade Policy Tracker. https://www.ifpri.org/project/covid-19-food-trade-policy-tracker (6 July 2020).

5. Mekić, C., Ćosić, M. (2019). Livestock and tourism development as concept of conservation of the specificity of rural area in the municipality of Petrovac on Mlava. Tourism International Scientific Conference Vrnjačka Banja - TISC, Vol. 4, No. 2, 153-171.

6. Mekić, C., Ćosić, M. (2020). Livestock and tourism as means to preserve the specificity of Prijepolje rural area. Tourism International Scientific Conference Vrnjačka Banja - TISC, Vol. 5, No. 2, 264-281. 
7. Mekić, C., Novaković, Z. (2013). Development of the animal husbandry as concept of preservation of the Sjenica municipality rural area. International Scientific Conference"Sustainalbe Agriculture and Rural Development in Terms of the Republics of Serbia Starategic Goals Realization Withing the Danube Region" (Thematic Proceedings), December, 5-7 ${ }^{\text {th }} 2013$, Hotel "Oplenac", Topola-Serbia, 903-920.

8. Mekić, C., Novaković, Z. (2018). Development of animal husbandry and tourism as concept of Homolje rural progression. Tourism International Scientific Conference Vrnjačka Banja - TISC, Vol. 3, No. 2, 591-608.

9. Milenković, S., Bošković, N. 2012. Razvojne tendencije ekoturizma Srbije [=Development tendencies of ecotourism in Serbia]. Teme, Vol. 36, No. 2, 483-99.

10. Pejanović, R., Vujović, S. (2008). Ruralni razvoj i agroturizam [=Rural development and agritourism]. Agroekonomika, Vol. 37-38, No. 37-38, 515.

11. Popesku, J., (2011). Menadžment turističke destinacije [=Tourist destination management]. Singidunum University, Belgrade.

12. Reardon, T., Bellemare, M.F., Zilberman, D. (2020). How COVID-19 May Disrupt Food Supply Chains in Developing Countries. IFPRI Research Post, 2 April 2020. https:// www.ifpri.org/blog/how-covid-19may-disrupt-food-supply-chains-developing-c ountries (23 April 2020).

13. Torero, M., (2020a). Without food, there can be no exit from the pandemic. Countries must join forces to avert a global food crisis from COVID-19. Nature 580, 588-589. https://doi.org/10.1038/d41586-02001181-3

14. Torero, M., (2020b). Prepare Food Systems for a Long-Haul Fight against COVID-19. IFPRI Blog, 2 July 2020. https://www.ifpri.org/blog/ prepare-food-systems-long-haul-fight -against-covid-19 (7 July 2020).

15. Unković, S., Sekulović N., (2010). Mere za ublažavane negativnog dejstva Svetske ekonomske krize na turizam [=Measures to mitigate the negative impact of the World Economic Crisis on tourism]. Singidunum revija, Vol. 7, No. 2, 181-192. 
16. Weersink, A., von Massow, M., McDougall, B., (2020). Economic thoughts on the potential implications of COVID-19 on the Canadian dairy and poultry sectors. Canadian Journal of Agricultural Economics. Vol. 68, No. 2, 1-6.

17. WFP (2020b). World Food Programme to Assist Largest Number of Hungry People Ever, as Coronavirus Devastates Poor Nations. https://www.wfp.org/news/world-food-programme-assist-largest-numberhungry-people-ever-coronavirus-devastates-poor (7 July 2020).

18. WFP, (2020a). 2020 - Global Report on Food Crises. https://docs.wfp.org/api/documents/WFP-0000114546/download/?_ga1/42. 110830339.728196019.1594181106-199106846.1593758578 (6 July 2020).

19. Republički zavod za statistiku Srbije (2014). Opštine i Regioni u Republici Srbiji. 